\title{
HAZAI VASBETON HÍDJAINK 100 ÉVÉNEK (1200-IG) ESZTÉTIKAI ÁTTEKINTÉSE
}

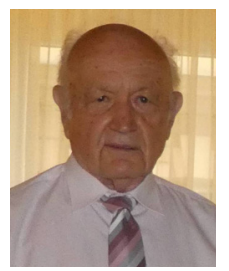

Dr. Tóth Ernő

https://doi.org/10.32969/VB.2020.4.1

A magyar közúti hidak között számos olyan vasbeton szerkezet van, amely esztétikai szempontból érdekes, bemutatásra méltó. A cikkben bemutatunk ezek közül néhányat és esztétikai szempontból összefoglalót adunk. Ez a cikk a 2018. novemberében tartott 3. hidesztétikai ankéton elhangzottt elöadás szerkesztett változata.

Kulcsszavak: vasbeton hidak, esztétika.

\section{A HIDAK BEMUTATÁSA}

A solti vasbeton boltozatú csatorna híd (1889)

A Monier-rendszerben épült hidat Zoltán Győző mérnök (ÁÉH) tervei szerint $5+5$ méteres nyílásokkal építették.

A híd boltozat alakra emlékeztet, az áttört mellvéd korlát célját szolgálja, 1942-ben megszélesítették. Ma gyalogosok is átmehetnek az egyik nyílás alatt, így a híd oldalról is jól látható. A hidat 2002-ben részben átépítették és teljes egészében felújították. Jó formájú, igényes kialakítású ez az eredeti alakjában álló első vasbeton közúti hidunk (1. ábra).

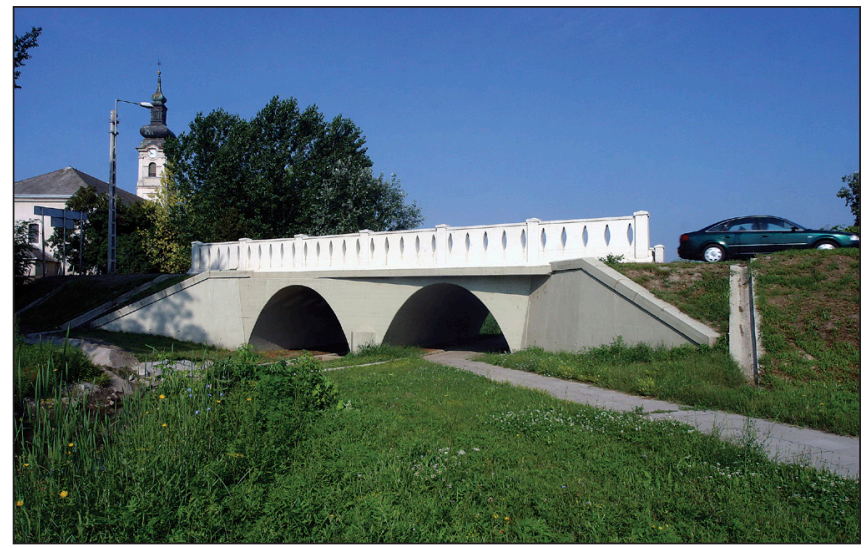

1. ábra: A solti vasbeton boltozatú csatorna híd

\section{A városligeti gyalogoshíd (1896)}

Wünsch-rendszerü hidak elsősorban a millennium idején épültek szerte az országban. Hazánk mai területén a Városligetben álló müemléki védettségü, ma funkció nélküli gyalogoshíd a legismertebb és a legjelesebb (2. ábra).

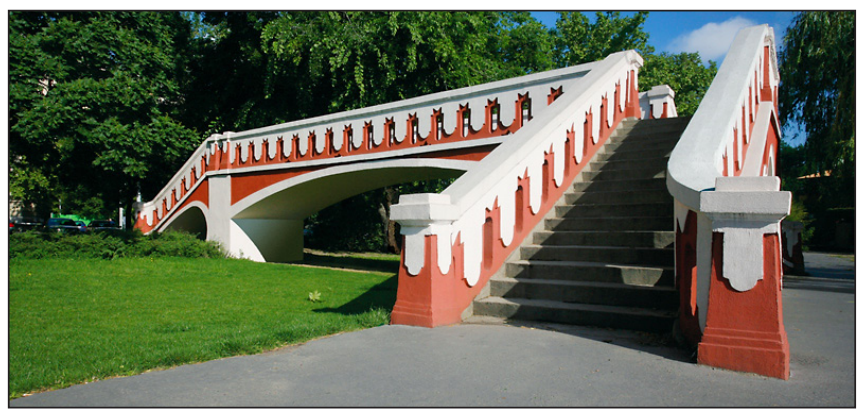

2. ábra: A városligeti gyalogoshíd

\section{A balatonföldvári Zielinski-féle gyalogoshíd (1905)}

Hennebique-rendszerrel, Zielinski Szilárd - a hazai vasbetonhíd-építés megteremtője - irodájának tervei szerint, 15-18 méteres nyílásokkal, 100 m összhosszal épült.

Vasbeton hídjaink zöme gerendaszerkezet, e híd érdekessége, hogy egyfötartós kialakítású. Igényes korláttal, eredeti formájában, javítások nélkül áll ez a becses müemlékünk (3. ábra).

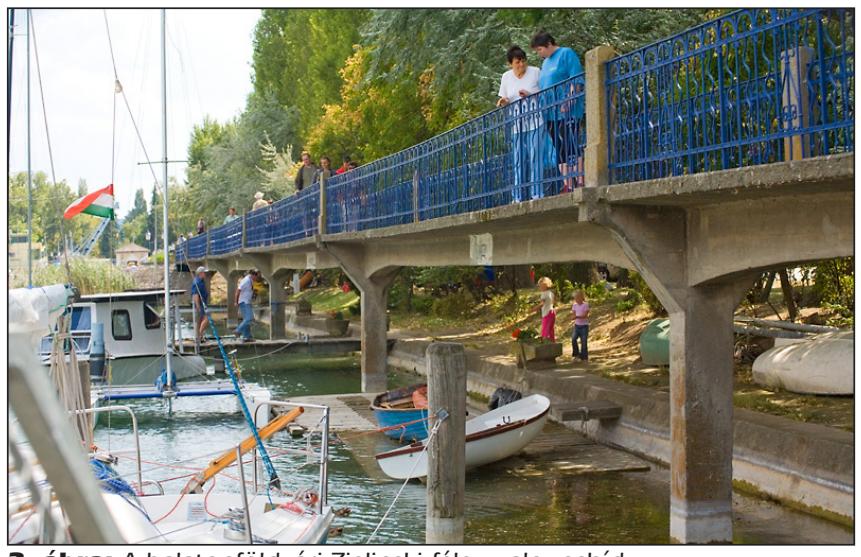

3. ábra: A balatonföldvári Zielinski-féle gyalogoshíd

Rábakecöl Répce-árapasztócsatorna hídja (1908)

Kovács Sebestyén Aladár tervei szerint épült ez a karcsú, többnyílású kerethíd, mely annak idején vízépítési típusszerkezet volt. A karcsú vasbeton szerkezet mindössze $150 \mathrm{~m}^{3}$ vasbetonból 1,8 t betonacéllal épült, $8+10+8$ méteres

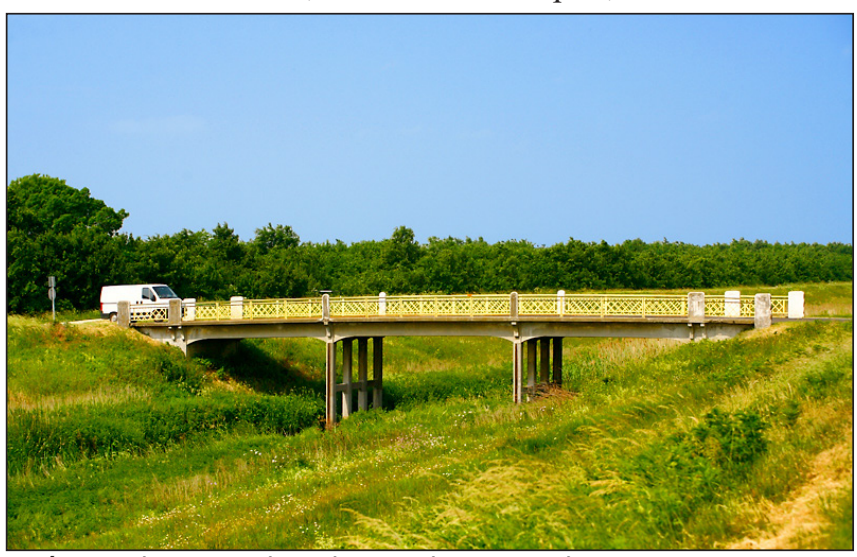

4. ábra: Rábakecöl Répce-árapasztócsatorna hídja 
nyílásokkal. Hazánk területén több ehhez hasonló hídszerkezet épült jelezve, hogy milyen fontos volt vízfolyásaink rendezése és elődeink milyen igényes, gazdaságos hídszerkezeteket terveztek és építettek (4. ábra).

\section{Körösszakál, Sebes-Körös-híd (1928)}

A négynyílású híd $(20+25+25+20 \mathrm{~m})$ Tóth Zsigmond tervei szerint épült. Vízfolyásainkon több fötartós, folytatólagos gerenda hidak általában páratlan számú nyílással épültek úgy, hogy a középső nyílás volt a legnagyobb. Ez a híd így az általános kialakítástól eltér, bemutatása azért indokolt, mert a II. világháborúban általában elpusztultak a hozzá hasonló szerkezetek, ez azonban lényegében eredeti formájában áll. Jellegzetes ezen a hídon is a rövid, egyenes kiékelés és a típus kialakítású korlát (5. ábra).



5. ábra: Körösszakál, Sebes-Körös-híd

A veszprémi Szent István völgyhíd (1937)

Folly Róbert tervei alapján két híd épült. Az egyik 45 méteres főnyílású, a másik 26+26 méteres ívekből áll. Összhosszuk $185 \mathrm{~m}$ (6. és 7. ábra).

A műemléki védettségű híd főnyílását a II. világháborúban név szerint is ismert, bátor helyiek védték meg, így az épségben maradt.

A völgyhíd az új 8. sz. fóút építésekor tudatos aprólékos tervezéssel nyerte el városképi értékét. A tervező harmadfokú parabolával alakította ki ezt a kecses, szép formájú hidat.

A 8. sz. foút építése során 20 jelentős híd épült neves tervezőink alkotásaként, így pl. Városlődnél egy kétnyílású ívhíd is. Kár, hogy különböző okok miatt ez már nem látható.

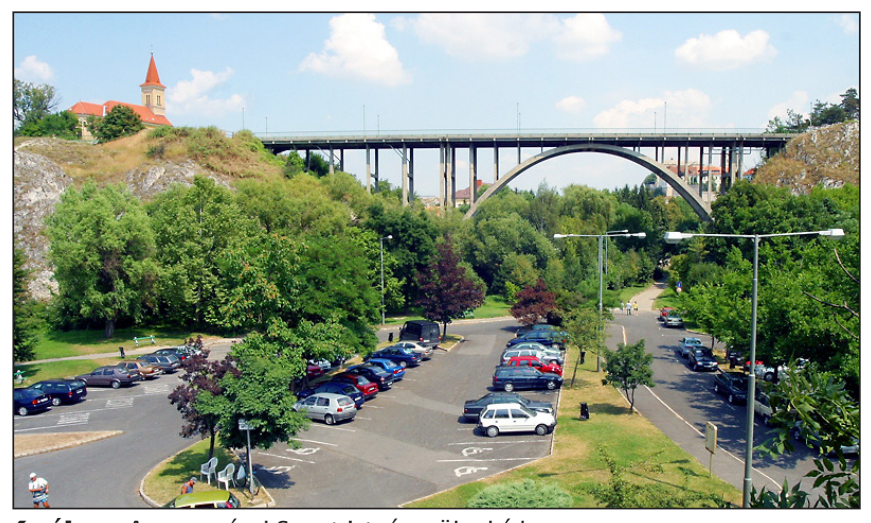

6. ábra: $A$ veszprémi Szent István völgyhíd

\section{A győri Sétatéri Rába-híd (1950)}

Az 52 m nyílású, igen karcsú, Gerber-csuklós híd Kemény Ádám (Uvaterv) tervei szerint épült 1,35 méteres szerkezeti magassággal (7. ábra). Később ennél nagyobb nyílású híd is épült, Budapesten, a Hajógyári-szigetnél 56 méteres nyílással.
Ez a hídtípus 1908-tól - először Temesváron - épült, közülük a Mihailich Győző tervezte híd építésekor világcsúcs méretű volt. Az akkor Temesváron épült több hasonló híd tervezésében kiváló építészmérnökök is közreműködtek, említésre méltó, hogy a Mihailich Győző tervezte híd ma is eredeti formájában áll.

Hazánk mai területén a györi Iparcsatornán és a Sión is épültek hasonló Gerber-csuklós hidak. Ez utóbbiak a mai napig szolgálják a forgalmat.

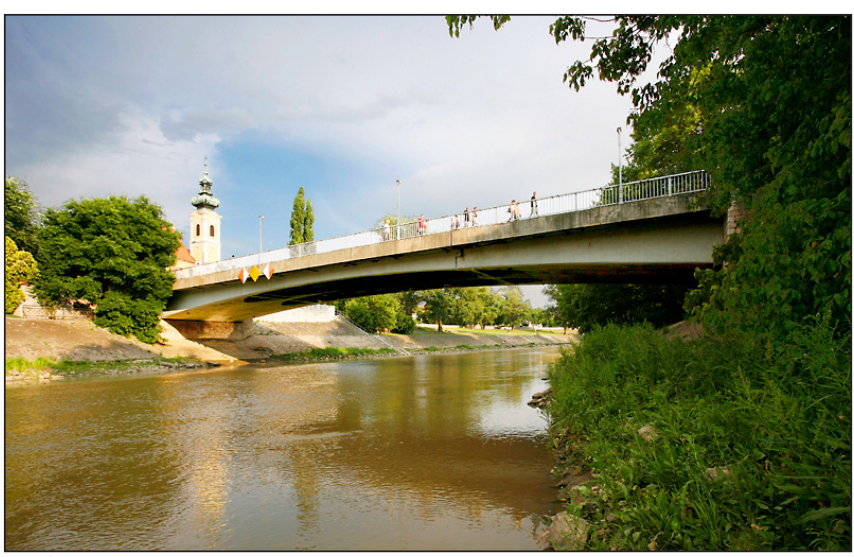

7. ábra: A győri Sétatéri Rába-híd

A Varasdi völgyhíd (1953)

A Bölcskei Elemér (Mélyépterv) tervezte híd 98 méteres nyílással, $170 \mathrm{~m}$ hosszban vezeti át az új 6 . sz. föutat a völgy fölött, 32. m magasságban. E híd a hídtervezés fejlődésének megfelelően a veszprémitől részleteiben eltérő kialakítású, tervezésekor neves szakértőkből álló bizottság segített abban, hogy a technika fejlődésének lehetőségével élve épüljön e híd. Jellemzö, hogy pl. kábeldaruval épült a híd, 25 zömben történt betonozással, az állvány 37 ütemben történt leeresztésével ( 8 . ábra).

A rendkívül látványos híd sajnos az azóta eltelt időben felnött növényzet miatt csak a régi útról vagy légi felvételen csodálható meg.

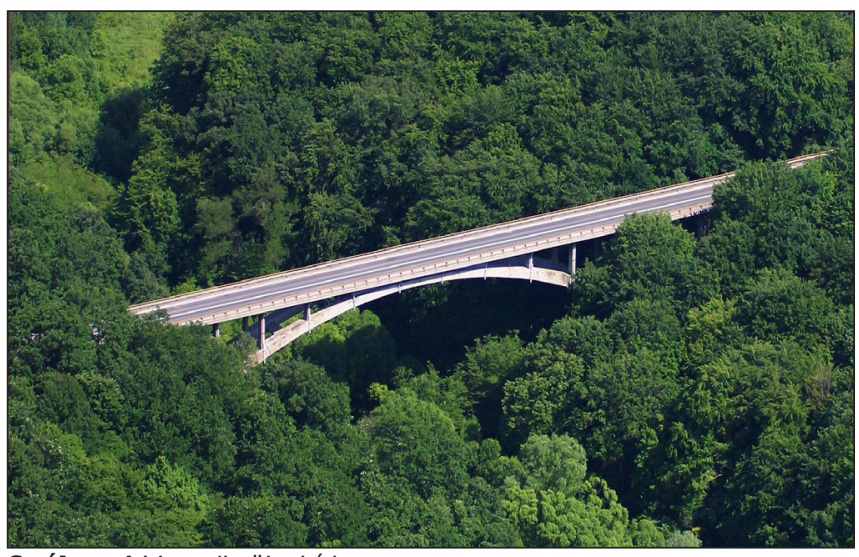

8. ábra: A Varasdi völgyhíd

\section{A Bolondúti völgyhíd (1954)}

Ez a híd is a 6. sz. föúton, Bölcskei Elemér alkotása. Az elöregyártás korai, túl merésznek is mondható építménye, a 25+3x30+25 m nyílású híd a 27 m mély völgy felett épült, így indokolt volt hatalmas állványozás helyett elöregyártott gerendákat alkalmazni (9. ábra).

A 40x185 cm keresztmetszetű vasbeton gerendák emelése több körülmény szerencsétlen összegeződése miatt az első emelésnél balesettel végződött. A keresztmetszet és a beemelés 
részbeni átalakítása után a gerendákat sikerrel emelték be.

Az 1950-ben kezdődött, feltétlenül indokolt előregyártás a továbbiakban kisebb nyílásokkal folytatódott és csak évtizedekkel később érte el a 40 m-t.

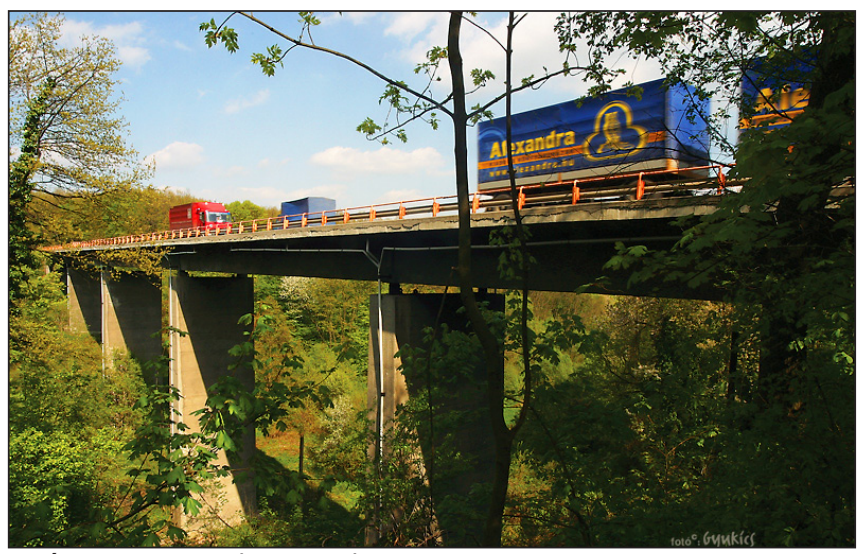

9. ábra: A Bolondúti völgyhíd

\section{A tiszalöki Keleti-fócsatorna-híd (1954)}

A Reiner Endre (Uvaterv) tervezte híd (10. ábra) azért említésre méltó, mert a Keleti-föcsatornán 20 ilyen híd épült. Hazánkban alsópályás ívhidak már 1935-37-ben épültek. Ma 34 hasonló, bár többféle rendszerü híd áll.

E hidakon keresztmetszeti kialakításban, vonóvas, vonókábel és más részek tekintetében sokféle, folyamatosan fejlődő megoldások találhatóak. A Reiner Endre tervezte híd 58 m nyílású.

E hídtípus síkvidéken rendkívül gazdaságos, tekintve, hogy szerkezeti magassága minden más szerkezeténél kisebb, ezért tervezőink igyekeztek megtalálni ennek a szerkezetnek a legjobb megoldását. Az alsópályás ívhidak egyik ,gyenge pontja" az elég nagyszámú felső keresztkötés, amelyek zavarhatják a jármüvezetőket elsősorban nem optikailag, hanem mivel fizikai akadályt jelentenek. Ezért jelentős az a gyakorlat, hogy több ilyen hídnál sikerült a legalacsonyabban lévő keresztkötéseket eltávolítani, illetve egy kisebb nyílású hídnál, Kecskédnél - Lipták László tervei szerint felsőkeresztkötés nélküli szerkezet is épült.

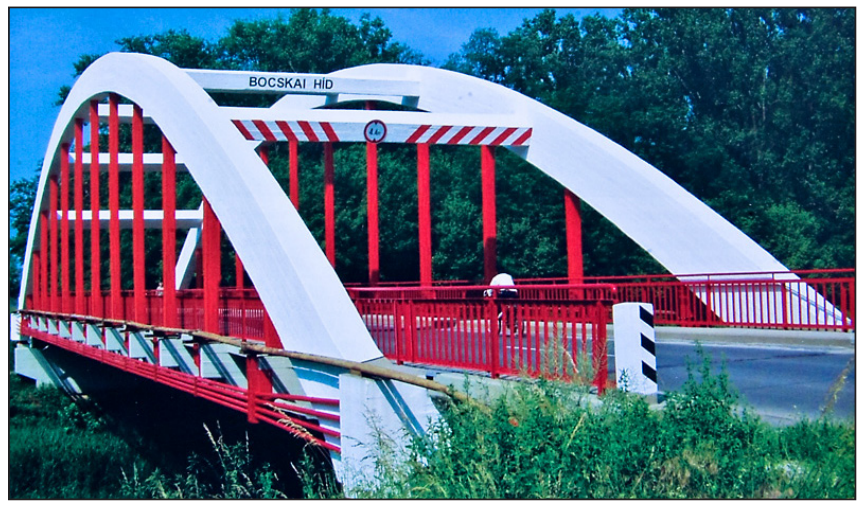

10. ábra: A tiszalöki Keleti-fócsatorna-híd

\section{A tihanyi hajóállomási híd (1961)}

Lipták László koncepciója és tervei szerint épült: felfelé szélesedő, sinus görbe mentén elhelyezett, kör keresztmetszetü pilléreken álló a híd szélei felé csökkenő vastagságú $80 \mathrm{~m}$ hosszú (10x8 méteres) tartószerkezet (11. ábra).

A híd a rendkívüli környezetben - apátsági templom, kikötőhíd, emlékmü - igen tetszetős, egyedülálló, kétségtelenül munkaigényes zsaluzású és talán ezért követésre nem talált példa, pedig a hagyományos vasbeton szerkezetektől kedvező irányban eltérö, a környezetbe kiválóan illeszkedő, jól fenntartható, igen kedvező szerkezet.

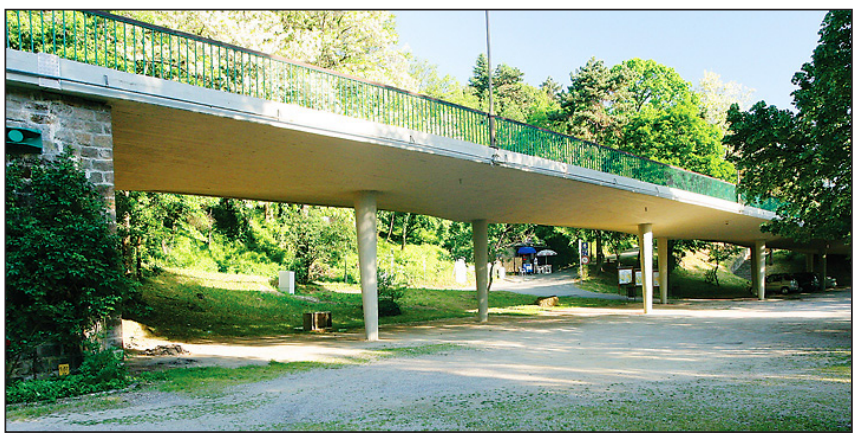

11. ábra: A tihanyi hajóállomási híd

Az Erzsébet híd budai lehajtó csomópontja (1964)

Loykó Miklós (Uvaterv) tervei alapján épült hazánk első nagyvonalú, többágú, íves vasbeton csomóponti hídja (12. ábra).

A 330 m összhosszúságú híd ívei a belső szegélyen csak 25 méter sugarúak, az egész hídon pedig csak 25 m hosszú egyenes található.

A tervező a szük hely miatt három, egymással két ponton összefüggő, többtámaszú, szekrénytartós szerkezetet alakított ki. Fontos szempont volt, hogy a híd minél kisebb tömegü legyen, minél kevesebbet foglaljon el a környezetéből. A terv jól sikerült, méltó az Erzsébet hídhoz

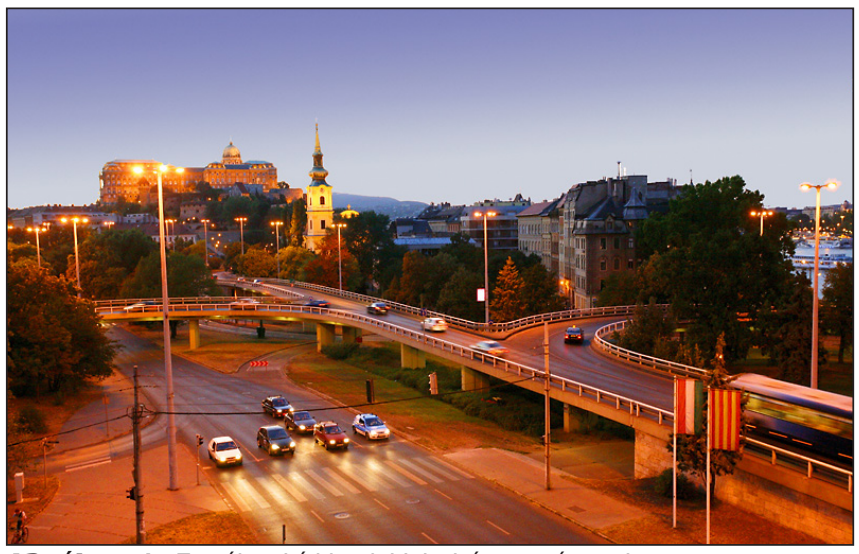

12. ábra: Az Erzsébet híd budai lehajtó csomópontja

A kápolnásnyéki pihenőhelyhez vezető gyalogos híd (1966) Az M7 autópálya felett Királyföldi Lajosné (Uvaterv) tervei szerint épült ez a rendkívül karcsú, nagy esésü, merész gyalogoshíd (13. ábra).

Bölcskei Elemér javaslatára 1952-ben épült először V-lábú és ferdelábú kerethíd.)

Az M7-es fölött épült $80 \mathrm{~m}$ hosszú híd ferdelábúnak

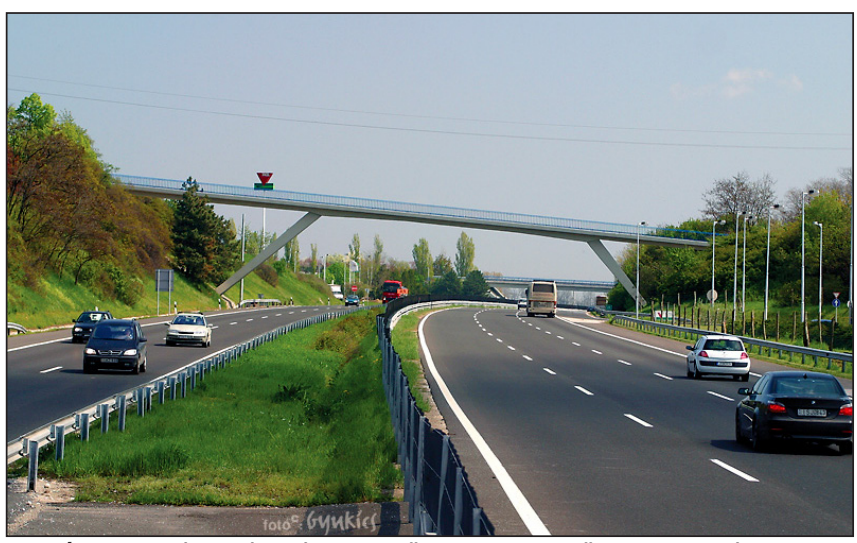

13. ábra: A kápolnásnyéki pihenőhelyhez vezető gyalogos híd 
látszik, valójában ez V-lábú kerethíd, mivel a statikában ez előnyösebbnek mutatkozott és a rézsük takarják a V-lábnak egyik részét. Az M7-es 14-es kilométerében egy valóban ferdelábú híd is épült, s egyáltalán a V-lábú és ferdelábú hidak is kedveltek mind a mai napig a tervezésben.

\section{A Flórián téri, Árpád hídra vezető hidak (1984)}

A Horváth Adrián (Főmterv) tervei szerint két, egyenként 11 nyílású híd épült. Ezek hossza 320, illetve 360 méter (14. ábra).

Müemléki védettségü helyen - római építészeti emlékek felett $\left(5000 \mathrm{~m}^{2}\right.$ fedett és $2300 \mathrm{~m}^{2}$ nyitott felület) - áll ez a monumentális hídszerkezet. Mindkét híd ívben fekszik, a legkisebb alaprajzi sugár $150 \mathrm{~m}$.

Nehéz adottság volt, hogy az építési idő kjorlátozott vlta miatt elöregyártott (egyedileg átalakított EHGT) tartókkal kellett a hidakat megépíteni és a fejgerendákat mindenhol csak egy oszlop támasztja alá. A római romok megőrzése mellett épült gyalogos aluljáró egyedülálló élményt nyújt, ismereteim szerint Európa-szerte. Az aprólékos, gondos tervezés monumentális, remek alkotást hozott létre.

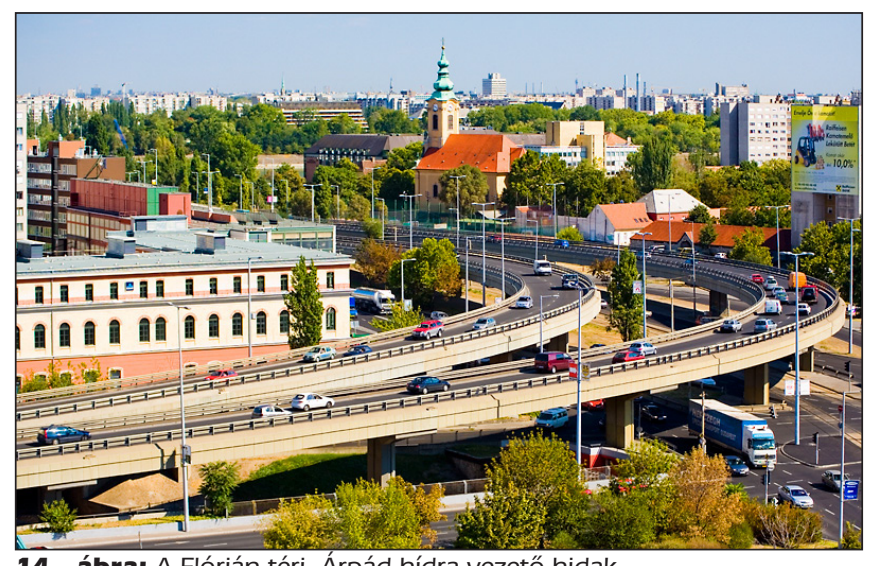

14. ábra: A Flórián téri, Árpád hídra vezető hidak

\section{Az M0 autóút hídja a Soroksári-Duna felett (1990)}

Varga József (Uvaterv) tervei szerint 36+75+36 méteres nyílású szabadbetonozásos technológiával épült a híd, melyhez összesen 18 nyílású előregyártott gerendás hídszerkezet csatlakozik, így a híd teljes hossza mintegy 500 méter (15. ábra).

A vasbeton folyami hidak építésére 1975-ben kialakított szabadszereléses technológia után 1979-ben a szabadbetonozás előtérbe helyezésével folytatódott a technológia fejlesztése, amit 1990-től a szakaszos elöregyártás technológiája tett teljessé.

Napjainkban a szabadszereléses technológia már csak ritkán alkalmazott, bár pl. a Körös-hegyi völgyhídnál különböző okok miatt a szabadbetonozás mellett szabadszerelést is alkalmaztak.

Ezek az új módszerek elönyösek, mert állványozást

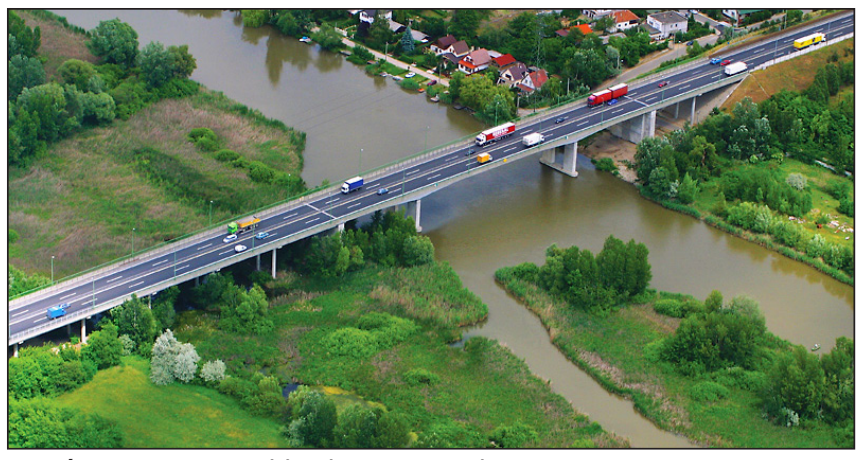

15. ábra: $A z$ MO autóút hídja a Soroksári-Duna felett lényegében nem igényelnek és az előbbiek alakja az erőjátékot követve gazdaságos.

A cikk képeit a 10. ábra kivételével Gyukics Péter fotómüvész készitette.

A továbbiakban néhány hídesztétikai elvet vázolok fel és irodalomjegyzéket adok annak érdekében, hogy az érdeklödö tájékozódjon ebben a szép, nehéz, folyamatosan változó hídesztétikai kérdésben.

\section{HÍDESZTÉTIKAI GONDOLATOK A SZAKIRODALOM ÉS SZEMÉ- LYES VÉLEMÉNYEM ALAPJÁN}

A hídesztétika az építőanyagok, építéstechnika, a számítások fejlődése, valamint a kor ízlésének megfelelően állandóan változik, tehát indokolt tanulmányozni.

A híd funkcióját (közúti, vasúti, gyalogos stb.) maradéktalanul ki kell elégíteni, esetleg később felmerülő újabb funkcióra is gondolni kell.

A híd felszerkezete az áthidalt nyílástól, az alkalmazott építőanyagtól függően (gerenda, ív, függesztett stb.) egy hídon belül lehetőleg homogén legyen.

A híd tartószerkezetét az erőjátéknak megfelelően, a kilátást lehetőleg nem zavaró tartóalakkal kell tervezni, az alak biztonságot sugárzó legyen.

A híd nyílásszáma, a nyílások mérete, az áthidalt akadályok alakja harmonikus legyen.

A híd felszerkezete, alépítménye és a hídfeljárók egymással kellö összhangban legyenek.

A híd egésze illeszkedjen a környezetéhez: sík vagy dombvidék, illetve beépített környezet.

Az autópályák feletti, külön szintü csomópontok hídjainál a gépkocsiból látható hidak alakjával, felületképzésével figyelemmel kell lenni a közlekedők hídélményére.

Városi hidaknál a gyalogosok szempontjaira figyelemmel kell lenni. Színezés, világítás lehetséges.

A hidak korlátjai fontos optikai elemek, ezek esztétikus kialakítására, biztonságos voltára külön gondot kell fordítani.

A hidak környékének növényekkel való kiemelésére gondolni kell úgy, hogy a természet ne foglalja el később a hidat, az állatok (pl. denevérek) megtelepedését meg kell akadályozni.

A hidat az út vonalvezetésébe harmonikusan kell behelyezni. Alsópályás hidaknál előny, hogy a jármüvezetők is látják a szerkezetet. A hossz-szelvényben a vízelvezetés fontossága miatt homorú vagy vízszintes hidat nem szabad tervezni.

Vasbeton, feszített vasbeton hidakat a téli sózásra figyelemmel kell tervezni.

Müemlék, müszaki emlék hidakat lehetőleg meg kell őrizni a jövő nemzedékeknek. Üzemeltetésük, felújításuk során az eredeti formák megtartása érdekében anyagi áldozatokat is kell hozni.

A hidak tervezésére vonatkozó szabályokban tömör, generális elveket kell rögzíteni. Különleges igények estén egyedi szabályozás lehet szükséges.

\section{3. ÖSSZEGEZÉS}

Hazánkban az országos közutakon mintegy 2,4 millió $\mathrm{m}^{2}$ hídszerkezet áll, ennek mintegy 90\%-a vasbeton anyagú, hídjaink alépítménye pedig kevés kivételtől eltekintve 
mindenhol vasbeton szerkezet. Ezért a vasbeton hidak esztétikája rendkívül fontos, hisz zömében ezzel találkozik az utazó. A bemutatott példák 2004-ig mutatják be hazai hídállományunk ide vonatkozó részét, amely természetesen ennél sokkal változatosabb, mégis remélhetőleg egy átfogó képet adunk hazai hídjainkról.

A tervezés mellett hídjaink esztétikai megjelenése egy sor más tényezőtől is függ. A kivitelezés gondossága, a híd élettartama alatti rongálódások, átázások, javítások mind káros mértékben rontják hídjaink megjelenését, ezért is kell arra törekedni, hogy tartós, jól fenntartható hídszerkezetek épüljenek és mindent tegyünk meg hídjaink károkozása ellen. Így igen fontos a közutak sózásának minimális mértéken tartása, hisz ez az egyik károkozó, másrészt a jármüütközés elleni védelem szintén kulcskérdés.

\section{IRODALOMJEGYZÉK}

Bölcskei E. (1951): „V lábú szerkezetek”, MSz 1951/6

Bölcskei E., Láng-Miticzky Cs. (1959): Vasbeton hidak, Müszaki Könyvkiadó

Harkányi J. (1939): „Hídépítések a Budapest-Gráci államvasúton”, TECHNIKA

Huszár Gy. (1976): „Közúti hidak esztétikája, MSz 1976/1

Juhász B. - Loykó M. (1978): „Vasbeton híd- és szerkezetek építése”, Tankönyvkiadó

Kara K. - Tóth E. (2007): „Hídjaink, A római örökségtől a mai óriásokig”, Közlekedésfejlesztési Koordinációs Központ

Kászonyi G. (1979): „Mérnöki létesítmények esztétikai kérdései”, Doktori értekezés
Lipták L. (1962): „A tihanyi felüljáró”, MSz 1962/11

Kollár L. - Vámosy F. (1996): „Mérnöki alkotások esztétikája”, Akadémiai Kiadó

Jankó L. (1998): „Vasbeton hídszerkezetek, I-II.”, Egyetemi jegyzet

Medved G. (2001): „Történetek a világ hídjairól”, TERC

Menyhárd I. (1942): „A mérnöki építészet esztétikája”, Magyar Mérnök és Épitészegylet Közlönye Negyedévi szemle, Épitészet 1942/2

Széchy K. (1942): „A hidak esztétikája”, Magyar Mérnök és Épitészegylet Közlönye Negyedévi szemle, Épitészet, 1942/2

Palotás L. (1957): „Mérnöki kézikönyv”, Müszaki Könyvkiadó

Palotás L. (1963): „Mérnöki szerkezetek kialakítása különös tekintettel azok esztétikájára", MSz 1963/11

Palotás L., Medved G., Nemeskéri-Kiss G., Träger H. (1987): „Hidak”, Müszaki Könyvkiadó

Petúr A. (1973): „Hídszerkezetek esztétikája”, MSz 1973/1

Dr. Tóth Ernő (1937) okl. mérnök, útépítési szakmérnök. 1961-69 között hídügyi előadó. 1969-79 között osztályvezető a székesfehérvári Közúti Igazgatóságon, majd 1979-88-ig Budapesten fejlesztési ösztályvezető az UKIG elődjét képező, többször változó nevű szervezetben. 1988-89-ben a Közlekedési Minisztérim hídosztályának vezetője. Ezt követően az Országos Közúti Főigazgatóság, majd az UKIG hídosztályán foglalkozott az országos közutak hídjaival. Szakmai pályafutása során így tevékenysége hidakra és utakra terjedt ki beleértve azok fenntartását és korszerüsítését is. A fib magyar Tagozat tagja.

\section{AESTETHETICAL REVIEW OF HUNGARIAN REINFORCED CONCRETE BRIDGES OF THE LAST CENTURY UNTIL 1990 Ernö Tóth}

Among the Hungarian highway bridges there are many concrete structures, which are esthetically interesting. In the article we show some of them and gives an aesthetical summarization.

\title{
BETONTECHNOLÓGUS SZAKIRÁNYÚ TOVÁBBKÉPZÉS A BME ÉPÍTŐMÉRNÖKI KARÁN 2021-2022
}

\author{
A BME Építőanyagok és Magasépítés Tanszék szervezésében induló négy féléves kurzusra várjuk \\ az érdeklődő kollégák szíves jelentkezését
}

A betonnal szembeni fokozott elvárások (pl. nagy szilárdság, tartósság, veszélyes hulladékok tárolása stb.), a speciális igényeket kielégítő betonok kifejlődésének és az európai szabványok megjelenésének hatására a betontechnológia jelentősége egyre nagyobb hangsúlyt kap és érdeklödésre tart számot napjainkban.

A BME ÉMK Építőanyagok és Magasépités Tanszék a diplomával záruló Betontechnológus Szakirányú Továbbképzése a betontechnológia körébe tartozó legújabb ismeretek átadásával kívánja segíteni a praktizáló kollégákat. Saját, jól felfogott érdekében minden cégnek rendelkeznie kell jó betontechnológussal.

A továbbképzés célja, hogy a résztvevők megszerezzék a legfrissebb betontechnológiai ismereteket. Ennek érdekében a hallgatók a betontechnológiai módszerek mellett elmélyedhetnek a speciális tulajdonságú betonok témakörében, a betonalkotók anyagtani kérdéseiben, az építőanyagok újrahasznosításában, a környezetvédelmi kérdésekben, a betonstruktúra elemzésében és annak hatásában a tartósságra, a diagnosztika nyújtotta lehetőségekben - aminek eredményei megfelelő javítási vagy megerősítési mód kiválasztását teszik lehetővé, a mély és magasépítési szerkezetek betontechnológiai szempontból jelentős tervezési és kivitelezési kérdéseiben -, a betongyártás és előregyártásban, a minőségirányítás és minőségbiztosítás módszereiben, valamint áttekintést kapnak a vasbetonépítésben megjelent legújabb anyagokról is a tanfolyamon.

Mindezen ismereteknek még fokozottabb jelentősége van az MSZ EN 206:2014 európai betióonszabvány és az MSZ 4798:2016 “Beton. Müszaki követelmények, tulajdonságok, készités és megfelelöség, valamint az EN 206 alkalmazási feltételei Magyarországon” szabvány megjelenése óta.

A tananyag egymásra épülő rendszerben áttekinti a betontechnológiához szükséges összes ismeretanyagot, valamint a hozzájuk kapcsolódó jogi, gazdasági és vezetéselméleti kérdéseket.

A négy féléves képzés (legalább szakirányú BSc diplomával) levelező rendszerben történik - félévenként 3-3 konferenciahét általában hétfő 10.00-től csütörtök 16.00-ig - amely az utolsó félévben szakdolgozat készítéssel zárul.

A következö tanfolyam kezdete: 2021. március 22.

Jelentkezési határidö: $\quad$ 2021. március 22.

A jelentkezéshez kérjük csatolja:

- a végzettséget igazoló oklevél másolatát,

- $\quad$ szakmai önéletrajzot.

További információ, ill. kérdés esetén forduljon Sánta Ildikóhoz (tel: (1) 463-4068, e-mail: titkars@eik.bme.hu).

A tanfolyam részletes leírása és a jelentkezési lap a

http://www.em.bme.hu/em/betontechnologus internetes oldalon található.

Dr. Balázs L. György tanfolyamvezetö tanár balazs.gyorgy@epito.bme.hu 